\title{
Empirical analysis of board diversity and the financial performance deposit money banks in Nigeria
}

\author{
A.D. Adesanmi ${ }^{*}$, O.A. Sanyaolu ${ }^{a}$, M.A. Isiaka ${ }^{a}$ and O.A. Fadipe ${ }^{a}$
}

${ }^{a}$ Bells University of Technology, Nigeria

\begin{tabular}{l}
\hline C H R O N I C L E \\
\hline Article history: \\
Received April 112019 \\
Received in revised format April \\
242019 \\
Accepted May 12019 \\
Available online \\
May 32019 \\
\hline Keywords: \\
Board diversity \\
Board independence \\
Gender diversity \\
Financial performance \\
Deposit Money Banks
\end{tabular}

\begin{abstract}
A B S T R A C T
This study examined the effect of board diversity on the financial performance of deposit money banks in Nigeria. The study also examined the relationship between board independence and financial performance of deposit money banks in Nigeria. For the purpose of this study, the proxy for financial performance is profit margin while the proxies for board diversity and board independence are the ratio of female directors to total board size and ratio of non-executive directors to total board size, respectively. The data for the study were sourced from the annual reports of 10 listed deposit money banks in Nigeria from 2008 to 2017. The data were analyzed using pooled Ordinary Least Square regression. The results show that the coefficient of board diversity was positively signed and statistically significant at $5 \%(\beta=0.34, \rho=0.02)$; the coefficient of board independence was positively signed and statistically significant at $5 \%(\beta=$ $0.11, \rho=0.02)$. The study concludes that both gender diversity and board independence positively affect the financial performance of deposit money banks in Nigeria. Therefore, the study recommends that deposit money banks should encourage appointment of qualified female directors on the board. In addition, deposit money banks should ensure the independence of the board by appointing independent non-executive director who are well experienced in bank management.
\end{abstract}

(C) 2019 by the authors; licensee Growing Science, Canada

\section{Introduction}

Corporate governance is the system by which business corporations are directed and controlled. The corporate governance structure specifies the distribution of the rights and the responsibilities among different participants in the corporation, and spells out the rules and procedures for making decisions on corporate affairs. Such participants include the board, managers, shareholders and other stakeholders. Corporate governance also provides the structure through which the company objectives are set, and the means of attaining those objectives and monitoring performance. The Board of Directors is saddled with the responsibility of decision making on behalf of the shareholders. Agency theorists argue that in order to protect the shareholders' interests, the board of directors must assume an effective oversight function. It is assumed that board performance of its monitoring duties is influenced by the effectiveness of the board, which in turn is influenced by factors such as board composition and quality, size of board, gender diversity, ethnic diversity and foreign directorship. 
Agency problem arises whenever managers have incentives to pursue their own interest (self-serving behavior) at the expense of shareholders. Most studies on corporate governance focus on how to effectively monitor the agents (resolving the conflict) against self- serving behavior in order to protect shareholders interest. The board of directors is one of the most influential decision-making bodies. Its responsibilities span from making key financial and strategic decisions, such as approving changes in capital structure and mergers and acquisitions, to the difficult task of choosing the company's top executive leadership (Ferreira \& Gyourko, 2014). The board is often noted as having four key functions: monitoring and controlling managers, providing information and counsel to managers, monitoring compliance with applicable laws and regulations, and linking the corporation to the external environment (Mallin, 2004; Monks \& Minow, 2004). Trend from the changes and reviews of corporate governance codes reveals that there is a need to continuously investigate characteristics of boards that will improve performance and reduce corporate failures and scandals. For example, the Security and Exchange Commission (SEC) in 2003, put forward that, the financial sector attracted poor corporate governance due to the fact that, only about $40 \%$ of quoted companies, including banks had recognized codes of corporate governance in place. Consequently, in 2003, a Code of Best Practices on Corporate Governance for public quoted companies was released by the Nigerian Securities and Exchange Commission (SEC). However, in 2006, the consolidation of the banking industry necessitated a review of the existing code for the Nigerian Banks. The new code therefore was developed to compliment the earlier ones and enhance their effectiveness for the Nigerian banking industry. Compliance with the provisions of the Code was mandatory. Again, in advancement of the banking reforms, the Central Bank of Nigeria in May 2010, issued guidelines to address some corporate governance issues not expressly addressed in the initial code of corporate governance, like the tenure of the Chief Executive Officers (CEO).

The economic case for a diverse board is that board diversity causes a business to be more profitable and creates value for shareholders. This argument implies that diverse directors are not perfect substitutes with identical ability and talents but diverse directors have unique characteristics that create additional value. Since the banking sector is the bedrock of any economy, there is need to focus attention on the board composition and diversity to guard against the failure of this sector of the economy. This study has great significance due to the fact that few studies of this nature have been carried out in African countries and other less developing countries. Boards of directors have been largely blamed for decrease in shareholder's wealth and corporate failure. They have been blamed for the fraud cases that had resulted to the failure of major corporations, such as Enron, WorldCom and Global Crossing. In Nigeria, a series of widely-publicized cases of accounting improprieties have been recorded. Examples include the case of Wema Bank, Finbank and Spring Bank, and more recently Skye Bank.

Some of the reasons stated for these corporate failures are the lack of vigilant oversight functions by the board of directors, the board relinquishing control to corporate managers who pursue their own self-interests and the board being remiss in its accountability to stakeholders. As a result, various corporate governance reforms have specifically emphasized on appropriate changes to be made to the board of directors in terms of its composition, structure and ownership configuration and constituting strategic resources to the organization. Various studies on corporate governance have mainly focused on the size of the board as well as composition in terms of executive and non-executive. Most of these studies have failed to examine how is the diversity of the board, in terms of gender of the directors, affect the performance of firms. 


\section{Literature Review and Theoretical Framework}

\subsection{Theoretical Review}

The relevant theoretical perspectives that relates to the focus of this study include the popular Agency Theory, the Stakeholder's theory and the Resource Dependency theory. Each of these are discussed in this section.

\section{a) Agency Theory}

Agency theory is based on the fact that many corporate managers are not owners but agents of owners, contracted to manage the company on their behalf (Ujunwa et al., 2012). According to Fama and Jensen (1983), the board of directors is one of several important mechanisms that control and monitor managers and plays a vital role in the managerial policies of the companies. The board of directors aims to solve agency problems between managers and shareholders (Dang et al., 2013). Based on this theory, the presence of women and foreign directors will increase the board's effectiveness and firm performance. The basic premise is that diversity may lessen the tendency for boards to engage in groupthink (Ujunwa et al., 2012). Agency theorists also indicate that having women, ethnic minorities, and foreigners as external stakeholders may bring fresh solutions to complex issues (Francoeur et al., 2007). For instance, female directors might be more active in monitoring and controlling managers by asking more questions and bringing different perspectives to the boardroom (Dang et al., 2013). Furthermore, diversity will increase board independence because people with a different gender, ethnicity, or cultural background might ask questions that would not come from directors with traditional backgrounds (Carter et al., 2008, 2010). Hence, diverse boards will improve firm performance by increasing board independence.

\section{b) Stakeholder's theory}

The stakeholders' theory provides that the firm is a system of stakeholders operating within the larger system of the host society that provides the necessary legal and market infrastructure for the firm's activities. The purpose of the firm is to create wealth or value for its stakeholders by converting their stakes into goods and services. This view is supported by Blair (1995) who proposes that the goal of directors and management should be maximizing total wealth creation of the firm. The key to achieving this is to enhance the voice of and provide ownership-like incentives to those participants in the firm who contribute or control critical, specialized inputs (firm specific human capital) and to align the interests of these critical stakeholders with the interests of outside, passive shareholders. Sundaram and Inkpen (2004) also suggest that stakeholder theory is appropriate for analysing whether management gives more attention to the interest of some stakeholders relative to others.

\section{c) Resource Dependency theory}

Resource dependence theory (RDT) studies how external resources of company affect its behavior and strategy. Company should have control of its critical resources so that it is not dependent on other parties. This theory is related to the contact role of board of director in which companies seek to manage external dependency by forming ownership ties and board connections (Nicholson \& Kiel, 2007; Thomsen \& Conyon, 2012). In a review by Hillman et al. (2002), the authors identified four primary benefits for the external linkages which are: provision of specific resources such as expertise information or advice from individuals with experience in a variety of areas, creation of channels of communication to the firm; provision of commitments of support from important organizations in external environment; creation of legitimacy for the firm. Board ties and connections provide opportunities and access to valuable resources for companies. Hillman et al. (2002) state that different types of directors provide different beneficial resources to the company, such as: advice, legitimacy and outside information. Hence, a more diverse board will provide more variations and more valuable resources, which lead to better firm performance. Among other corporate governance theories, resource dependence theory provides the most convincing theoretical basis for board diversity and its effect on 
firm performance. Concerning with this, Carter et al. (2010) point out that gender and ethnic diversity in the board provide unique information sets for management to make better decision. Diverse directors give access to important constituencies in external environments. Moreover, board diversity sends positive signals to the market and diverse directors bring various perspectives and non-traditional approaches to problem solving. To support that, Ruigrok et al. (2007) add that the increasing internationalization of business leads to a higher demand for directors who possess necessary knowledge and contacts in foreign markets. In this case, foreign director might be qualified and be able to link the company to different contexts of the countries in which it operates. Likewise, with the increasing involvement of women in business world, the importance of female representation on corporate boards is also rising (Burke \& Mattis, 2000; Ruigrok et al., 2007; Salloum et al., 2019).

\subsection{Empirical review}

Otuya et al. (2017) examined the effect of banks' board globalizing on financial performance of quoted banks in Nigeria. The study made use of secondary data, which were obtained from the annual reports of ten banks for the years 2011- 2015. The study made use of the following variables: Board of Directors, Board Globalizing, Financial Performance, Asset Growth and Bank Riskiness. The study adopted the ordinary least square (OLS) regression as the basic techniques of data analysis. The authors found that foreign board membership, asset growth and institutional ownership have a significant positive relationship with financial performance of banks.

Matanda et al. (2015) examined the relationship between corporate board independence and the performance of commercial banks in Kenya for the period spanning 2001 to 2013. The study made use of Return on assets, Return on Equity and Tobin Q Ratio. A panel data regression analysis was used in analyzing the variables under consideration. The study recommended that if commercial banks in Kenya are to improve their performance they should direct their efforts towards other variables other than board composition. Garba and Abubakar (2014) examined the relationship between board diversity and financial performance of insurance companies in Nigeria. The study selected 12 listed insurance companies using non-probability sampling method in the form of availability sampling technique for a period of 6 years (2004 to 2009). The authors used descriptive statistics and panel regression method to analyze the data collected for the purpose of the study. The study revealed that gender diversity and foreign directors have a positive influence on insurance companies' performance.

Saleh (2016) investigated the effect of the board of directors' attributes on the financial performance of deposit money banks in Nigeria during the period 2009-2014. The study adopted panel multiple regression technique of data analysis. The study recommended that in order for the Security and Exchange Commission and Central Bank of Nigeria to improve performance in deposit money banks, good corporate governance practices must be implemented, this should include improving board attributes, especially the functional background of the directors. Uadiale (2010) examined the impact of board structure on corporate financial performance in Nigeria. The study made use of companies listed on the floor of the Nigerian Stock Exchange. Board structure, Corporate financial performance, Board ownership and Duality are the variables used. Ordinary Least Squares (OLS) regression was used to estimate the relationship between corporate performance measures and board structure of the Nigerian firms. The study suggested that large board size should be encouraged and the composition of outside directors as members of the board should be sustained and improved upon to enhance corporate financial performance. Bebeji et al. (2015) analyzed the effects of board size and board composition on the performance of Nigerian banks. Board size, board composition and financial performance are the variables employed to achieve the study objective. Regression analysis and Correlation matrix was used to analyze the financial statements of five banks as a sample for a period of nine years. The study concluded that banks should have adequate board size to the scale and

complexity of the organization's operations and be composed in such a way as to ensure diversity of experience without compromising independence, compatibility, integrity and availability of members 
to attend meetings. Agyei and Owusu (2014) explored the relationship between ownership structure and corporate governance and capital structure of some listed manufacturing companies on Ghana Stock Exchange. The study covered the period 2007 to 2011. Descriptive analysis, correlation analysis and multivariate regression technique were the tool of analysis. The study discovered that Board Size, Board Composition, Institutional and Managerial shareholding are positively and significantly correlated with leverage ratio, whereas CEO/Chair duality has a negative impact. Moscu (2013) investigated the relationship between Firm Performance and Board Characteristics in Romania. This study analyzed 62 firms listed on the Bucharest Stock Exchange in 2010. The study stated that an increase in the size of the board of management be encouraged as it leads to increased profitability, diversity and information in the company.

Khan and Awan (2012) explored the effect of board composition on firm's performance, specifically a case of Pakistani listed companies. A sample of 91 listed companies at Karachi stock exchange was examined. The independent sample t-test and group Statistics were used as the most appropriate techniques for data Analysis. The study recommended that companies should have independent directors in their board composition which will show greater firm performance. Ujunwa et al. (2012) investigated the impact of corporate board diversity on the financial performance of Nigerian quoted firms. The scope covered from 1991-2008. Least Square Regression was used to examine the impact of board diversity on firm performance. The study suggested that foreign board members would provide a firm with better qualified candidates who have broader industry experience. Additionally, the presence of women on the board could be perceived by shareholders as a sign of impending significant change.

\section{Methodology}

This study modelled performance as a function of gender diversity, board diversity, board composition and board independence. The model is implicitly specified as:

$\mathrm{PERF}=f$ (gender diversity, board size, board compensation, board independence)

This is stated in econometric form as follows:

$$
P M_{\mathrm{i}, t}=\beta_{0}+\beta_{1} B C O M_{i t}+\beta_{2} B S_{i t}+\beta_{3} B I N D_{i t}+\beta_{4} B G D_{i t}+\mu_{i t}
$$

where

$\begin{array}{ll}P M=\text { Profit Margin } & i=\text { number of banks } \\ B C O M=\text { board compensation } & t=\text { period/time } \\ B S=\text { Board size } & \mu=\text { error term } \\ B I N D=\text { Board Independence } & \beta_{0,} \beta_{1}, \beta_{2}, \beta_{3}, \beta_{4} \text { are coefficient of explanatory variables } \\ B G D=\text { Board gender diversity } & \end{array}$

\section{Result and Discussion}

The panel regression result shows the estimate of the effect of gender diversity on financial performance of the sampled banks. The result shows that the coefficient of multiple determination $\mathrm{R}^{2}=0.58$, indicating that about $58 \%$ of the total variation in the dependent variable (profit margin) is explained by the independent variables (Board gender diversity, Board independence, Board size and Board compensation). 


\section{Table 1}

The results of the regression model

\begin{tabular}{crrrr}
\hline Variable & Coefficient & Std. Error & t-Statistic & Prob. \\
\hline LCOM & 0.005530 & 0.006473 & 0.854384 & 0.0053 \\
BS & 0.001647 & 0.002244 & 0.733967 & 0.0450 \\
BIND & 0.110587 & 0.044965 & 2.459415 & 0.0159 \\
BGD & 0.033609 & 0.095155 & 0.353206 & 0.0248 \\
C & 0.046328 & 0.089794 & 0.515944 & 0.6072 \\
\hline
\end{tabular}

Cross-section fixed (dummy variables)

Effects Specification

Weighted Statistics

\begin{tabular}{llll}
\hline R-squared & 0.581619 & & \\
Adjusted R-squared & 0.518376 & & \\
F-statistic & 9.196500 & Durbin-Watson stat & 1.996157 \\
Prob(F-statistic) & 0.000000 & & \\
\hline Sources: Author's computation 2018 & &
\end{tabular}

The F-statistics value is statistically significant at 5\% level, indicating that the model is significant. The Durbin-Watson of 1.996 indicates that the result is free from serial auto correlation problem. The coefficient of board gender diversity is 0.034 with p-value of 0.0248 , which is less than critical value of 0.05 for board gender diversity, this is statistically significant and it indicates that there is positive relationship between board gender diversity and financial performance in the sampled banks in Nigeria. This suggests that a unit increase in the proportion of female on the board will lead to $3 \%$ increase in the financial performance of the selected banks. The result also shows that coefficient of board independence is 0.11 with a p-value of 0.0159 , which is less than critical value of 0.05 for board independence, which indicates that there is positive and significant relationship between board independence and financial performance of sampled banks. This shows that a unit increase in board independence will result to $11 \%$ increase in financial performance of the sampled bank. Furthermore, the result also revealed that the coefficient of board size is 0.001647 and p-value of 0.0450 which is less than critical value of 0.05 of board size, this indicate that there is a positive and significant relationship between the board size and financial performance. More so, the result also reveal that there is a positive and significant relationship between board compensation and financial performance with 0.01 as a coefficient of board compensation and 0.0053 as the associated p-value.

The study finds that there was a positive relationship between board gender diversity and financial performance. This implies that the presence of female directors on the board of banks has positive effect on the financial performance of banks. This can be likened to the role women play in home front. The role of women in the family cannot be over-emphasized for the success of the family as they are good managers of resources and make decisions that effect on the family positively. The finding of this study corroborates this assertion. This finding is similar to the conclusion drawn by Garba and Abubakar (2014), Ujunwa et al. (2012) and Ruuska (2017). The study also finds out that there is a positive and significant relationship between board independence and financial performance of selected banks. This means that upholding good governance improves financial performance. This is consistent with the conclusion drawn by Otuya et al. (2017), Saleh (2016), Khan and Awan (2012).

Furthermore, the result of this study shows a positive and significant relationship between board size and financial performance. This signifies that increase in board size will lead to increase in profit margin. This means the number of directors on the board has a synergistic effect on the decision making of the board, which eventually leads to better financial performance of the selected banks in Nigeria. This finding is similar to Uadiale (2010), Bebeji et al. (2015), Moscu,(2013), Darmadi (2013). In addition, the result indicates that board compensation had positive and significant relationship with financial performance. When directors are motivated, this has a great impact on financial performance 
because it is the board members that will formulate policies and make decisions which will have great impact on the overall financial performance of the organization.

\section{Concluding Remarks and Recommendation}

The study investigated the effect of board diversity on financial performance of deposit money banks in Nigeria. The study has found that there was a positive relationship between board gender diversity and financial performance. This implies that the presence of female directors on the board of banks has positive effect on the financial performance of banks. This can be likened to the role women play in home front. The role of women in the family cannot be over-emphasized for the success of the family as they are good managers of resources and make decisions that effect on the family positively. Based on the findings and conclusion from the study, in order to have a good corporate governance in the banking sector, the current study recommends that more female representation on the board should be mandated since it has been proved statistically that gender diversity will increase the performance of deposit money banks since women are good managers of resources and make decisions that effect on the family positively. In addition, the independence of board should also be reviewed. It is recommended that appropriate combination of executive and non-executive directors should be maintained so that it can influence positively on the financial performance of deposit money banks in Nigeria.

\section{References}

Agyei, A., \& Owusu, A. R. (2014). The effect of ownership structure and corporate governance on capital structure of Ghanaian listed manufacturing companies. International Journal of Academic Research in Accounting, Finance and Management Sciences, 4(1), 109-118.

Bebeji, A., Mohammed, A., \& Tanko, M. (2015). The effect of board size and composition on the financial performance of banks in Nigeria. African Journal of Business Management, 9(16), 590598.

Blair, R. J. R. (1995). A cognitive developmental approach to morality: Investigating the psychopath. Cognition, 57(1), 1-29.

Burke, R. J., \& Mattis, M. C. (Eds.). (2013). Women on corporate boards of directors: International challenges and opportunities (Vol. 14). Springer Science \& Business Media.

Carter, D., D'Souza, F. P., Simkins, B. J., \& Simpson, W. G. (2008). The diversity of corporate board committees and financial performance. Available at SSRN 1106698..

Carter, D. A., D'Souza, F., Simkins, B. J., \& Simpson, W. G. (2010). The gender and ethnic diversity of US boards and board committees and firm financial performance. Corporate Governance: An International Review, 18(5), 396-414.

Dang, R., Nguyen, D. K., \& Vo, L. C. (2013). Women on corporate boards and firm performance: A comparative study. Retrieved December, 11, 2013.

Darmadi, S. (2013). Do women in top management affect firm performance? Evidence from Indonesia. Corporate Governance: The international journal of business in society, 13(3), 288-304.

Fama, E. F., \& Jensen, M. C. (1983). Separation of ownership and control. The journal of law and Economics, 26(2), 301-325.

Ferreira, F., \& Gyourko, J. (2014). Does gender matter for political leadership? The case of US mayors. Journal of Public Economics, 112, 24-39.

Francoeur, C., Labelle, R., \& Sinclair-Desgagné, B. (2008). Gender diversity in corporate governance and top management. Journal of business ethics, 81(1), 83-95.

Garba, T., \& Abubakar, B.A. (2014). Corporate board diversity and financial performance of insurance companies in Nigeria. Asian Economic and Financial Review, 4(2), 257-277

Sundaram, A. K., \& Inkpen, A. C. (2004). The corporate objective revisited. Organization science, $15(3), 350-363$.

Ujunwa, A. (2012). Board characteristics and the financial performance of Nigerian quoted firms. Corporate Governance: The international journal of business in society, 12(5), 656-674. 
Hillman, A. J., Cannella Jr, A. A., \& Harris, I. C. (2002). Women and racial minorities in the boardroom: how do directors differ?. Journal of management, 28(6), 747-763.

Khan, A., \& Awan, S. H. (2012). Effect of board composition on firm's performance: A case of Pakistani listed companies. Interdisciplinary Journal of Contemporary Research in Business, 3(10), 853-863.

Mallin, C.A. (2004). Corporate Governance. Oxford University Press, Oxford.

Matanda, J.W., Luke, O., \& Lishernga Lisiolo, J. (2015). Relationship between board composition and performance of commercial banks in Kenya. Research Journal of Finance and Accounting, 6(14), $78-88$.

Monks, R., \& Minow, N. (2004). Corporate governance, vol. 3. Blackwell Publishing, Malden, MA.

Moscu, R. G. (2013). The relationship between firm performance and board characteristics in Romania. International Journal of academic research in economics and management sciences, 2(1), 167.

Nicholson, G. J., \& Kiel, G. C. (2007). Can directors impact performance? A case-based test of three theories of corporate governance. Corporate Governance: An International Review, 15(4), 585-608.

Otuya, S., Donwa, P. A., \& Egware, N. (2017). Earnings management and quality of corporate governance in Nigeria: A review of executive compensation and audit committee characteristics. Journal of Accounting and Financial Management, 3(3), 2017.

Ruigrok, W., Amann, W., \& Wagner, H. (2007). The internationalization-performance relationship at Swiss firms: A test of the S-shape and extreme degrees of internationalization. Management International Review, 47(3), 349-368.

Sunday, O., \& Godwin, O. (2017). Effects of Board Globalizing on Financial Performance of Banks in Nigeria. International Journal of Academic Research in Accounting, Finance and Management Sciences, 7(4), 1-10.

Saleh, M. (2016). Effect of Board of Directors' Attributes on the Financial Performance of Listed Deposit Money Banks in Nigeria. www.iiste.org. 15.

Salloum, S. A., Al-Emran, M., Shaalan, K., \& Tarhini, A. (2019). Factors affecting the E-learning acceptance: A case study from UAE. Education and Information Technologies, 24(1), 509-530.

Thomsen, S., \& Conyon, M. (2012). Corporate governance: Mechanisms and systems. McGraw Hill.

Ujunwa, A., Okoyeuzu, C., \& Nwakoby, I. (2012). Corporate board diversity and firm performance:

Evidence from Nigeria. Revista de Management Comparat International, 13(4), 605.

Uadiale, O. M. (2010). The impact of board structure on corporate financial performance in Nigeria. International Journal of Business and Management, 5(10), 155.

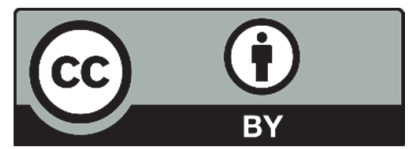

(C) 2019 by the authors; licensee Growing Science, Canada. This is an open access article distributed under the terms and conditions of the Creative Commons Attribution (CC-BY) license (http://creativecommons.org/licenses/by/4.0/). 